\title{
節付き場所打ちコンクリート杭の節部底面支持力算定式 BEARING CAPACITY FORMULAE FOR NODAL BASE OF NODULAR CAST-IN-PLACE CONCRETE PILE
}

\author{
八尾 眞太郎*, 伊 藤 淳 志**, 桝 井 健***, 伊 藤 仁**** \\ Shintaro YAO, Atsushi ITO, Takeshi MASUI \\ and Hitoshi ITO
}

\begin{abstract}
The ultimate bearing capacity formulae for nodal base of nodular cast-in-place concrete pile were led using axisymmetric analytical model based on rigid-plastic theory. In this model ratio of projecting width of node to radius of pile shaft and earth pressure in circumferential direction were considered, so the formulae are useful for calculating the ultimate bearing capacity of circular base of nodular pile. The propriety of the formulae were examined by comparing the calculated values with the results of vertical loading tests on model nodular piles.
\end{abstract}

\section{Keywords : Nodular pile, Ultimate bearing capacity, Skin resistance, Point resistance, Baring capacity factor, Axial symmetry \\ 節付き杭，極限支持力，周面抵抗，先端抵抗，支持力係数，軸対称問題}

1.はじめに

近年、建築物の高層化に伴って、大径の場所打ちコンクリート杭 を使用する機会が増加している。しかし、大径の杭は構造的に有利 な反面、排土量や鉄筋・コンクリート量などが増大し、コスト削減 や近年の環境問題に対する動向などに反する面も生じている。

これらの問題を解決するための方策として、先端支持力の增大を 図った拡底場所打ちコンクリート杭や、水平耐力の増大を図った拡 頭場所打ちコンクリート杭などが採用されている。これらを鑑みる と、図 1 のごとく場所打ちコンクリート杭の軸部に適当な間隔で拡 径した節を設けることによって、周面支持力を増大させるとともに、 排土量の減少やコンクリート量の削減を図ることも考えられる。

現在、上述したような節付き場所打ちコンクリート杭は使用され ておらず、工場生産の節杭”を使用しているのが現状である。節杭 の支持力機構に関しては、実験的研究として文献 ${ }^{2 \sim 5)}$ 、理論的研究 として文献 ${ }^{(8)}$ 等がある。特に、石堂 ${ }^{6,7)}$ の研究は節杭の支持力機構 を理論的に取り上げた最初のものであって、節部底面の極限支持力 を 2 次元の剛塑性論に基づく Prandtl 系の支持力理論によって考察 している。これらに対して、節付き場所打ちコンクリート杭の施工 性や支持力機構に関する研究はまだ見られないが、工場生産の節杭 とは異なることが予想される。
そこで筆者らは、節付き場所打ち コンクリート杭の開発および実用化 を前提として、その支持力機構を解 明するための研究を行っている。今 回その手始めとして、石堂 ${ }^{6,7)}$ が平面 問題として導いた節部底面の極限支 持力式を参考に、軸対称モデルによ る極限支持力算定式を誘導したので、 本論において報告する。

本論ではまず、節部底面の支持力 算定式の誘導過程を示し、支持力係 数式の提案を行う。次いで、杭先端 の支持力についても、同様のモデル によって導いた算定式を示す。さら に、これらの算定式による理論値と 模型実験結果との比較によって、算 定式の妥当性の検討を行う。

なお、本論文の一部については文 献9において報告済みであることをお 断りしておく。

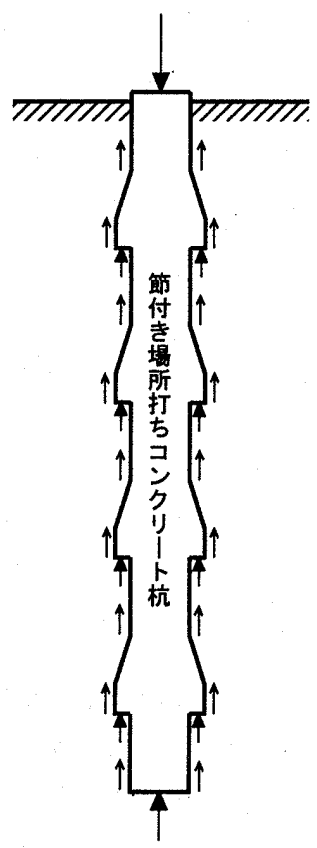

図 1 杭姿図
$*$ 関西大学工学部建築学科 教授.工博

** 関西大学工学部建築学科 助教授・博士 (工学)

*** 関西大学工学部建築学科 専任講師 ·博士 (工学) 侏)錢高組 修士 (工学)
Prof., Dept. of Architecture, Faculty of Engineering, Kansai University, Dr. Eng Assoc. Prof., Dept. of Architecture, Faculty of Engineering, Kansai University, Dr. Eng.

Lecturer, Dept. of Architecture, Faculty of Engineering, Kansai University, Dr. Eng. Zenitaka Corporation, M. Eng. 


\section{2. 節部底面の支持力式}

軸部半径が $R$ 、節部の突出幅が $a$ の節付き場所打ちコンクリート 杭について、地表面からの染さが $l$ の節部底面における極限支持力 の算定式を誘導する。モデル図を図 2 に示した。図 $2(a)$ に示す微 小な角度 $d \theta$ の範囲における節部底面（斜線部分）の支持力を $Q_{d}$ と し、下部地盤の破壊形として、図 $2(\mathrm{~b})$ のごとく $\triangle \mathrm{ABC}$ のくさび型 領域と ABD の放射状領域（BD は対数ら線）を考える。節付き杭 の周面支持力としては、節間隔が比較的小さい場合は節の外径に沿 った円筒状の地盤のせん断抵抗が、節閒隔がある程度大きい場合は 節部底面の支圧抵抗が支配的と考えられる ${ }^{101}$ 。本支持力算定式は後 者の場合を対象としているが、前者との対応を考慮して $\mathrm{AD}$ 面での 土圧の釣合をモデル化することとした。その際、軸対称条件の場合 にも、平面問題と同様のすべり線が生じるものと仮定した。極限時 には節部外周に発生するリングテンションによる地盤の緩みや、杭 の半径方向に放射状のクラックの発生などが考えられるためであ る。 $\mathrm{AD}$ 面には受働土圧 $p_{p}$ が、また円周方向には土圧 $p_{\theta}$ が作用し ているものとする。 $p_{p}$ としては、平面問題における Rankine や Coulomb の受働土圧、軸対称問題における球空洞押拡げ理論や円 柱空洞押拡げ理論の極限内圧 ${ }^{11}$ などが考えられるが、ここでは式の 簡便さを考慮して、Rankine の受働土圧を採用する。また、 $p_{\theta}$ は $Q_{d}$ によって生じる円周方向の土圧を考虑したものである。

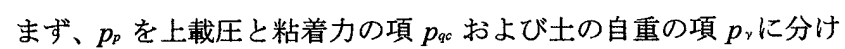
ると、p $p$ は次式のように表される。

$$
p_{p}=p_{q c}+p_{\gamma}=(q K+2 c \sqrt{K})+\gamma z K
$$

ただし、

$$
K=\tan ^{2}\left(\frac{\pi}{4}+\frac{\phi}{2}\right)
$$

ここに、 $q=\gamma l 、 c$ は粘着力、 $\gamma$ は土の単位体積重量であって、 $z$ は 節部底面からの梁さとする。したがって、 $\mathrm{AD}$ 面における $p_{p}$ の合力 $P_{p}$ は次式となる。

$$
\begin{aligned}
& P_{p}=P_{q c}+P_{\gamma} \\
& P_{q c}=p_{q c} r_{1}(a+R) d \theta=r_{1}(q K+2 c \sqrt{K})(a+R) d \theta \\
& P_{\gamma}=\int_{0}^{\eta_{1}} p_{\gamma}(a+R) d \theta d z=\frac{\gamma r_{1}^{2} K}{2}(a+R) d \theta
\end{aligned}
$$

ただし、

$$
\begin{aligned}
& r_{1}=r_{0} e^{\beta}, \quad r_{0}=\frac{a}{\cos \alpha} \\
& \beta=\left(\frac{\pi}{2}-\alpha\right) \tan \phi, \quad \alpha=\frac{\pi}{4}+\frac{\phi}{2}
\end{aligned}
$$

なお、 $\phi$ は土の内部摩擦角である。また、円周方向の土圧係数を $K$ 。 とすると、 $\mathrm{ABD}$ 面に作用する $p_{\theta}$ の合力 $P_{\theta}$ は式(8)となる。ただし、 式の簡便さを考虑して、作用面を $\triangle \mathrm{ABD}$ として近似してある。

$$
P_{\theta}=p_{\theta} \frac{a r_{1}}{2}=K_{\theta} \frac{Q_{d}}{\pi\left\{(R+a)^{2}-R^{2}\right\} \frac{d \theta}{2 \pi}} \frac{a r_{1}}{2}
$$

ここで、 $\mathrm{AB}$ 面に働く垂直力を $Q_{N}$ 、せん断力を $Q_{S} 、 \mathrm{ABD}$ で囲ま れた土の重量を $W_{1}$ として、 $\mathrm{ABD}$ に作用する力の $\mathrm{A}$ 点に関するモー

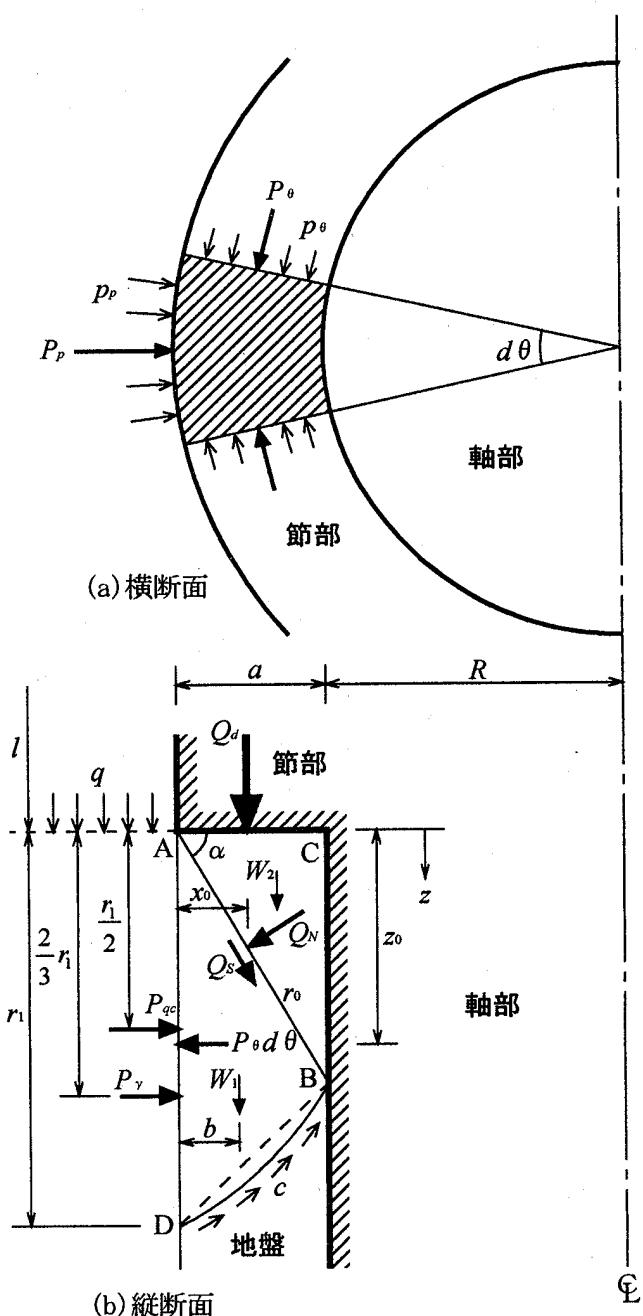

図 2 支持力モデル

メントの釣合を考えれば、以下の式が成り立つ。

$$
Q_{N} \frac{x_{0}}{\cos \alpha}=P_{q c} \frac{r_{1}}{2}+P_{\gamma} \frac{2 r_{1}}{3}-W_{1} b-2 P_{\theta} \frac{d \theta}{2} z_{0}+M_{c}
$$

$$
Q_{s}=Q_{N} \tan \phi+c A_{0}
$$

ここに、 $x_{0}$ は $\mathrm{A}$ 点から $Q_{N}$ および $Q_{S}$ の作用点（AB 面の重心位置と する）までの水平距離、 $z_{0}$ は $\mathrm{A}$ 点から $\triangle \mathrm{ABD}$ の重心位置までの梁 さ、 $A_{0}$ は $\mathrm{AB}$ 面の面積、 $M_{c}$ は $\mathrm{BD}$ 面の粘着力 $c$ によるモーメント であって、それぞれ次式となる。

$$
\begin{aligned}
& x_{0}=\frac{a(a+3 R)}{3(a+2 R)} \\
& z_{0}=\frac{r_{0} \sin \alpha+r_{1}}{3} \\
& A_{0}=\frac{r_{0}}{2}(a+2 R) d \theta \\
& M_{c}=\frac{c\left(r_{1}^{2}-r_{0}{ }^{2}\right)}{4 \tan \phi}(a+2 R) d \theta
\end{aligned}
$$

また、 $b$ は $\mathrm{A}$ 点から $W_{1}$ の作用点である $\mathrm{ABD}$ の土塊の重心位置ま での水平距離である。 
次に、 $\triangle \mathrm{ABC}$ に作用する力の鉛直方向の釣り合いを考えると、 節部底面の支持力 $Q_{d}$ は次式で表される。

$$
Q_{d}=Q_{S} \sin \alpha+Q_{N} \cos \alpha-W_{2}
$$

ただし、W $W_{2}$ は $\triangle \mathrm{ABC}$ で囲まれた土の重量である。

したがって、式(9)、式(10)および式(15)より、Q $Q_{a}$ が次式のよう に得られる。

$$
Q_{d}=\left(c N_{d c}+q N_{d q}+\gamma N_{d \gamma}\right) d \theta
$$

ここに、

$$
\begin{aligned}
N_{d c}= & \frac{3 a(a+R)(a+2 R) e^{2 \beta} \sqrt{K} \cos (\alpha-\phi)}{(a+3 R) \cos \alpha \cos \phi+K_{\theta} a e^{\beta}\left(\sin \alpha+e^{\beta}\right) \cos (\alpha-\phi)} \\
& +\frac{3 a(a+2 R)^{2}\left(e^{2 \beta}-1\right) \cos (\alpha-\phi)}{4 \tan \phi\left\{(a+3 R) \cos \alpha \cos \phi+K_{\theta} a e^{\beta}\left(\sin \alpha+e^{\beta}\right) \cos (\alpha-\phi)\right\}} \\
& +\frac{a(a+2 R)(a+3 R) \sin \alpha \cos \phi}{2\left\{(a+3 R) \cos \alpha \cos \phi+K_{\theta} a e^{\beta}\left(\sin \alpha+e^{\beta}\right) \cos (\alpha-\phi)\right\}}
\end{aligned}
$$

$$
\begin{aligned}
N_{d q}= & \frac{3 a(a+R)(a+2 R) e^{2 \beta} K \cos (\alpha-\phi)}{2\left\{(a+3 R) \cos \alpha \cos \phi+K_{\theta} a e^{\beta}\left(\sin \alpha+e^{\beta}\right) \cos (\alpha-\phi)\right\}} \\
N_{d y}= & \frac{a^{2}(a+R)(a+2 R) e^{3 \beta} K \cos (\alpha-\phi)}{\cos \alpha\left\{(a+3 R) \cos \alpha \cos \phi+K_{\theta} a e^{\beta}\left(\sin \alpha+e^{\beta}\right) \cos (\alpha-\phi)\right\}} \\
& -\frac{\cos \alpha}{a} \frac{3(a+2 R) \cos \alpha \cos (\alpha-\phi) W_{1}^{\prime} b+a(a+3 R) \cos \phi W_{2}^{\prime}}{(a+3 R) \cos \alpha \cos \phi+K_{\theta} a e^{\beta}\left(\sin \alpha+e^{\beta}\right) \cos (\alpha-\phi)}
\end{aligned}
$$

ただし、 $W_{1}^{\prime}=W_{1} / \gamma d \theta, W_{2}^{\prime}=W_{2} / \gamma d \theta$ とする。

以上より、式(16)の $Q_{d}$ を $\theta$ について積分することによって、軸 対称問題での節部底面の極限支持力 $Q$ は次式となる。

$$
Q=2 \pi\left(c N_{d c}+q N_{d q}+\gamma N_{d \gamma}\right)
$$

ここで検討の結果、 $W_{1}^{\prime}$ と $W_{2}^{\prime}$ 'は $Q$ にほとんど影響しないため、こ れらを無視して式 $(20)$ の両辺を節部底面積で割り、さらに $\omega=a / R$ と置き換えて無次元化すると、単位面積当たりの支持力 $q_{d}$ が次式 のように得られる。

$$
q_{d}=\frac{Q}{\pi\left\{(R+a)^{2}-R^{2}\right\}}=c N_{c}+q N_{q}+a \gamma N_{\gamma}
$$

ここに、

$$
\begin{aligned}
N_{c}= & \frac{6(\omega+1) e^{2 \beta} \sqrt{K} \cos (\alpha-\phi)+(\omega+3) \sin \alpha \cos \phi}{(\omega+3) \cos \alpha \cos \phi+K_{\theta} \omega e^{\beta}\left(\sin \alpha+e^{\beta}\right) \cos (\alpha-\phi)} \\
& +\frac{3(\omega+2)\left(e^{2 \beta}-1\right) \cos (\alpha-\phi)}{2 \tan \phi\left\{(\omega+3) \cos \alpha \cos \phi+K_{\theta} \omega e^{\beta}\left(\sin \alpha+e^{\beta}\right) \cos (\alpha-\phi)\right\}}
\end{aligned}
$$

$$
N_{q}=\frac{3(\omega+1) e^{2 \beta} K \cos (\alpha-\phi)}{(\omega+3) \cos \alpha \cos \phi+K_{\theta} \omega e^{\beta}\left(\sin \alpha+e^{\beta}\right) \cos (\alpha-\phi)}
$$

$$
N_{\gamma}=\frac{2(\omega+1) e^{3 \beta} K \cos (\alpha-\phi)}{\cos \alpha\left\{(\omega+3) \cos \alpha \cos \phi+K_{\theta} \omega e^{\beta}\left(\sin \alpha+e^{\beta}\right) \cos (\alpha-\phi)\right\}}
$$

式 $(22)$ 式 $(24)$ の支持力係数 $N_{c} 、 N_{q}$ および $N_{v}$ と $\phi$ との関倸とし て、 $K_{\theta}=0$ および $0.5 、 \omega=0.25$ および 0.5 の場合を図 3 〜図 5 に示した。また、 $\phi=35^{\circ} 、 K_{\theta}=0$ の場合の各支持力倸数と $\omega$ と の関係を図 6 に、 $\phi=35^{\circ} 、 \omega=0.5$ の場合の各支持力係数と $K_{\theta}$ との関係を図 7 に示した。なお、図 6 における $\omega=0$ での各支持力

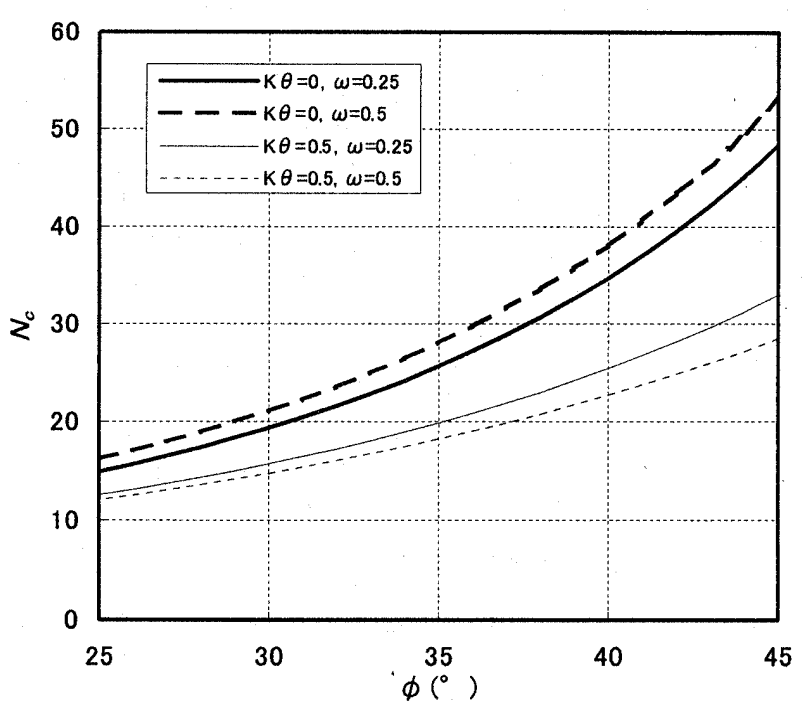

図 3 支持力係数 $N_{c}$

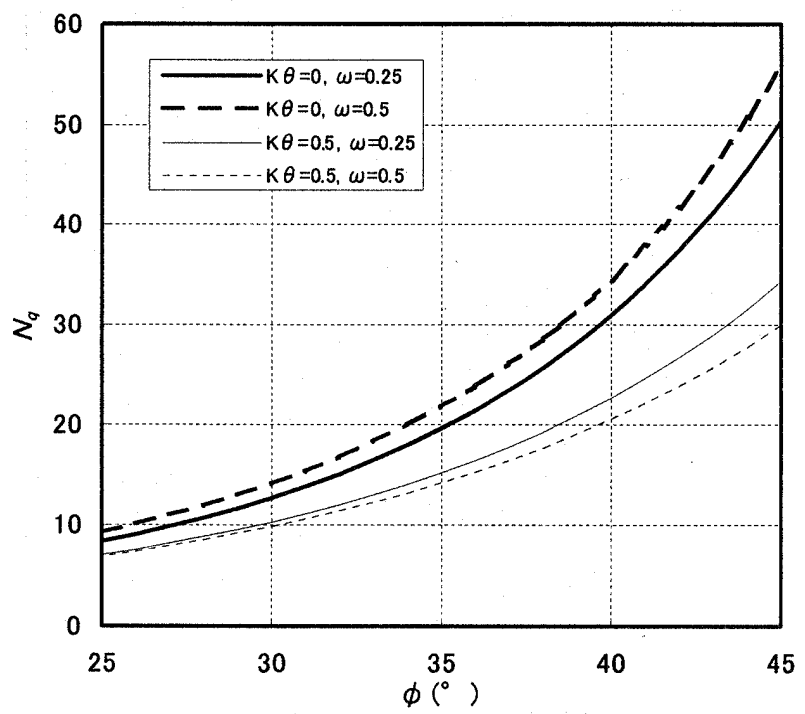

図 4 支持力係数 $N_{q}$

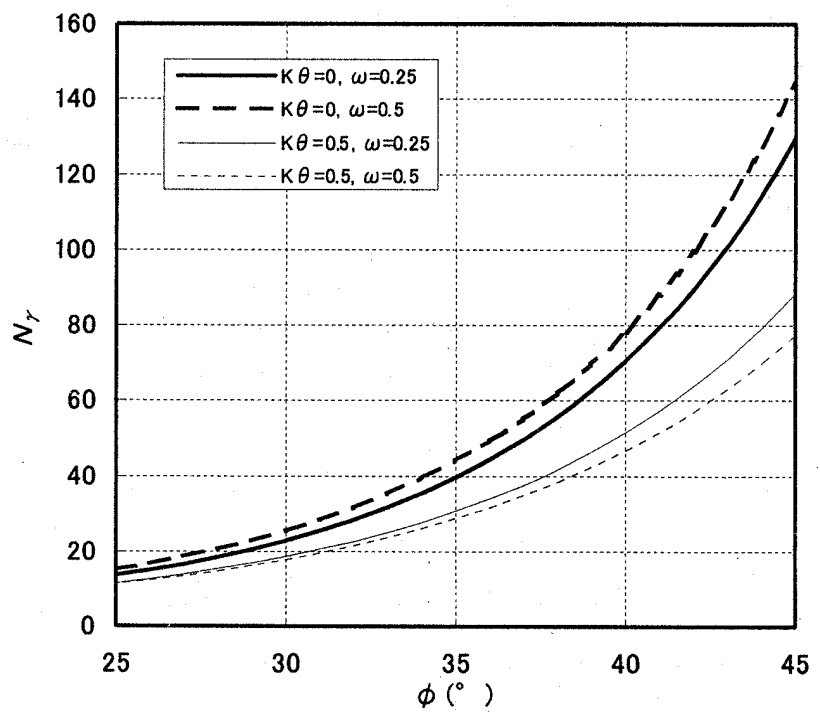

図 5 支持力保数 $N_{y}$ 


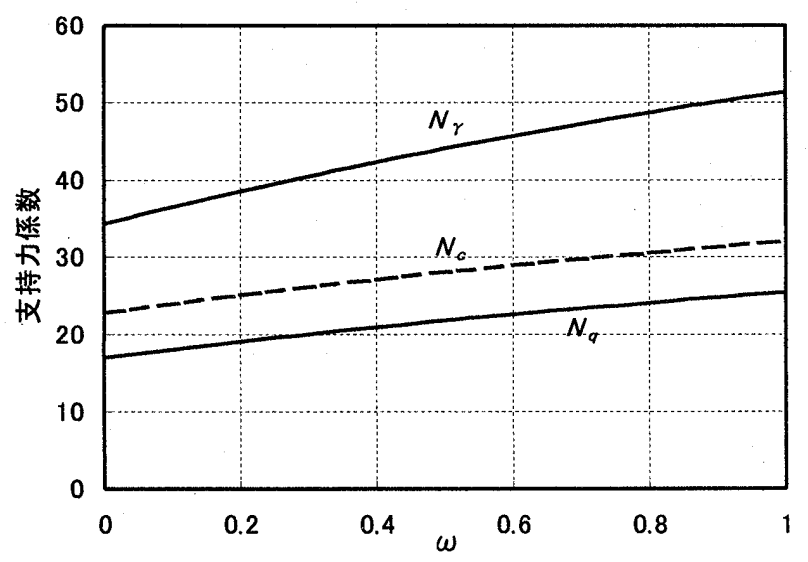

図6 支持力保数 $\left(\phi=35^{\circ}, K_{\theta}=0\right)$

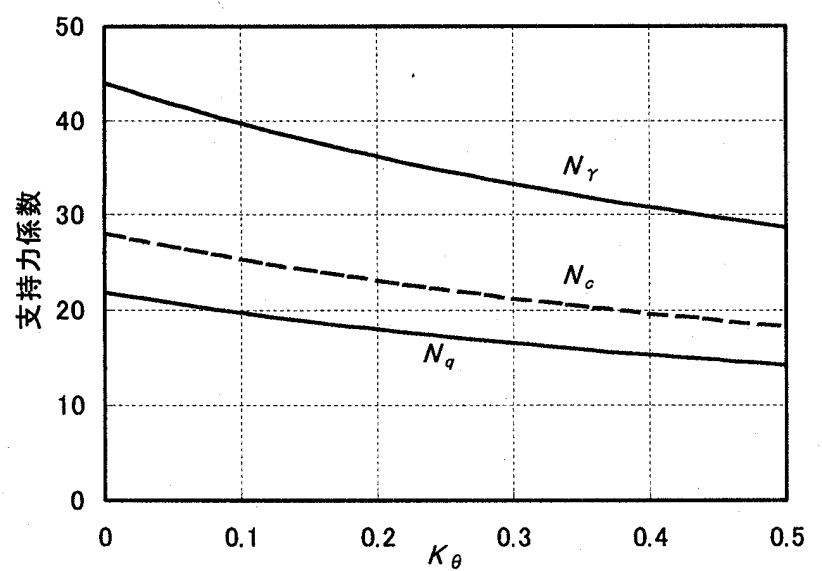

図 7 支持力係数 $\left(\phi=35^{\circ}, \omega=0.5\right)$

係数の值は $R=\infty$ 場合を意味しており、布基礎に相当している。 また、 $\omega=\infty$ とすると $R=0$ を意味し、次節で述べるように円形基 礎の場合に相当している。

\section{3. 杭先端の支持力式}

前節で誘導した節部底面の支持力算定式と同様に、図 2 において $R=0$ とした軸対象モデルを用いて、杭先端の極限支持力算定式を 求めた。結果として、杭先端での単位面積当たりの支持力 $q_{p}$ は次 式となる。

$$
q_{p}=c N_{p c}+q N_{p q}+a \gamma N_{p \gamma}
$$

ここに、

$$
\begin{aligned}
N_{p c}= & \frac{6 e^{2 \beta} \sqrt{K} \cos (\alpha-\phi)+\sin \alpha \cos \phi}{\cos \alpha \cos \phi+K_{\theta} e^{\beta}\left(\sin \alpha+e^{\beta}\right) \cos (\alpha-\phi)} \\
& +\frac{3\left(e^{2 \beta}-1\right) \cos (\alpha-\phi)}{2 \tan \phi\left\{\cos \alpha \cos \phi+K_{\theta} e^{\beta}\left(\sin \alpha+e^{\beta}\right) \cos (\alpha-\phi)\right\}} \\
N_{p q}= & \frac{3 e^{2 \beta} K \cos (\alpha-\phi)}{\cos \alpha \cos \phi+K_{\theta} e^{\beta}\left(\sin \alpha+e^{\beta}\right) \cos (\alpha-\phi)} \\
N_{p \gamma}= & \frac{2 e^{3 \beta} K \cos (\alpha-\phi)}{\cos \alpha\left\{\cos \alpha \cos \phi+K_{\theta} e^{\beta}\left(\sin \alpha+e^{\beta}\right) \cos (\alpha-\phi)\right\}}
\end{aligned}
$$

ただし、式(25)において $a$ は杭先端の半径を表す。また、式(26)〜 式(28)の各支持力係数は、前節での式 (22) 〜式 (24)において $\omega を$
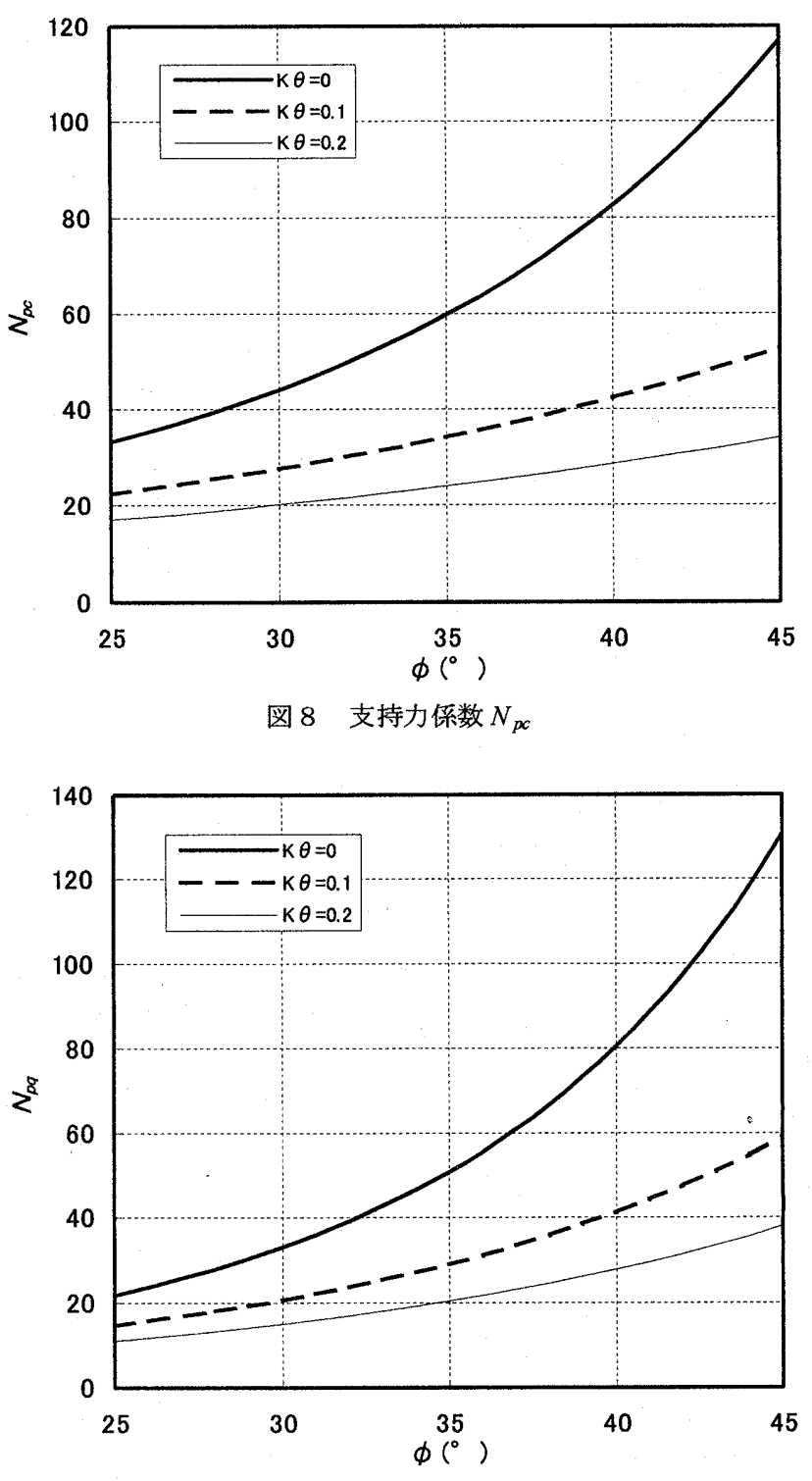

図 9 支持力倸数 $N_{p q}$

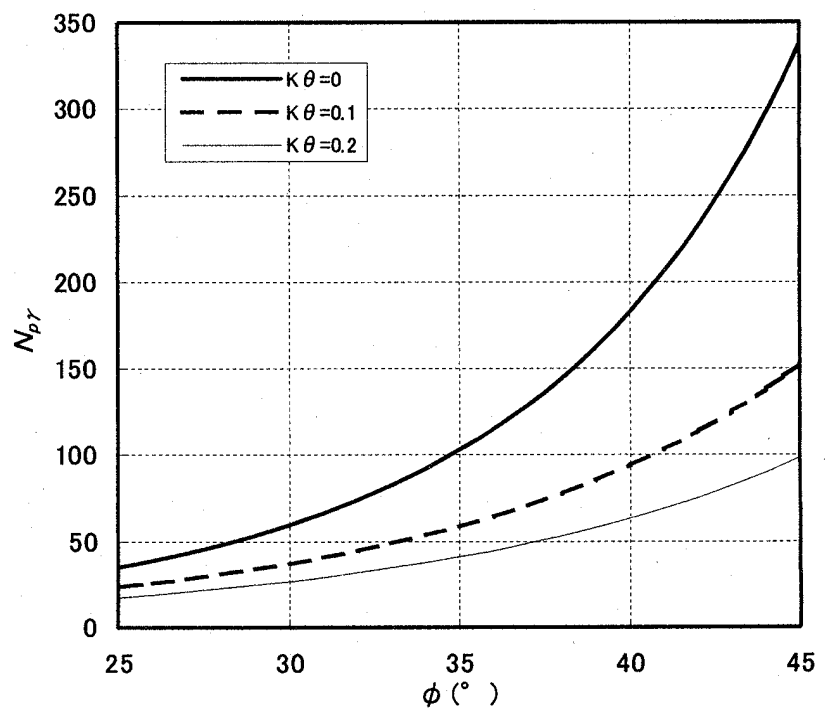

図10 支持力係数 $N_{p y}$ 
無限大とした式に一致していることが分かる。図 8 〜図 10 に支持 力係数と $\phi$ との関係を、 $K_{\theta}=0,0.1$ および 0.2 の場合について示 しておいた。

ここで、本論の支持力算定式による円形基礎（ $\omega=\infty$ の場合）お よび布基礎（ $\omega=0$ の場合）の各支持力係数について、建築基礎構 造設計指針 ${ }^{12)}$ (以下、指針と略称) で提示されている支持力保数と の比較を行う。同女献での支持力式は值接基礎に関する Terzaghi の支持力式 ${ }^{13}$ に基づいており、単位面積当たりの支持力 $q_{*}$ は次式と なる。

$$
q_{u}=a_{1} c N_{c}+\gamma D_{f} N_{q}+a_{2} \gamma B N_{\gamma}
$$

ここに、

$$
\begin{aligned}
& N_{q}=\frac{1+\sin \phi}{1-\sin \phi} e^{\pi \tan \phi} \\
& N_{c}=\left(N_{q}-1\right) \cot \phi \\
& N_{\gamma}=\left(N_{q}-1\right) \tan (1.4 \phi)
\end{aligned}
$$

なお、 $B$ は基礎幅、 $D_{f}$ は基礎根入れ染さであって、 $\gamma D_{f}$ は本論で の $q$ に相当する。また、 $a_{1}$ および $a_{2}$ は形状係数で、

$$
\begin{array}{ll}
\text { 円形基礎の場合 }: a_{1}=1.2, a_{2}=0.3 \\
\text { 布基礎の場合 } \quad: \quad a_{1}=1.0, a_{2}=0.5
\end{array}
$$
となる。

図 11 〜図 13 に、本論と指針の支持力係数を比較して示した。 ただし、本論の値は $K_{\theta}=0$ としてあり、指針は形状係数を掛けた 值としてある。図 11 の $N_{6}$ および図 12 の布基礎の $N_{q}$ については、 $\phi=30 \sim 40^{\circ}$ の範囲において本論と指針との值が概ね一致して いるが、その他については本論の方が大きくなる結果となった。

\section{4. 理論値と実験値との比較}

式(21)の節部底面支持力式および式(25)の杭先端支持力式によっ て、模型節付き杭の鉛直載荷実騦 ${ }^{14)}$ 対象とした理論計算を行い、 実験結果との比較検討を行った。実験に用いた杭はアルミニウム製 で、図 14 に示すごとく軸部径 $40 \mathrm{~mm}$ （肉厚 $3 \mathrm{~mm}$ ）、節部径 $60 \mathrm{~mm}$ 、 節の厚さ $20 \mathrm{~mm}$ であって、根入れ長さ $600 \mathrm{~mm}$ に対して節数が 3 個（節間隔 $240 \mathrm{~mm}$ ）、5 個（同 $120 \mathrm{~mm}$ ）および 9 個（同 $60 \mathrm{~mm}$ ） の 3 種類がある。なお、軸部内面には、図 14 に示す位置に軸方向 力測定のためのひずみゲージを貼り付けてある。地盤は粒径 $1.2 \mathrm{~mm}$ 以下の淀川砂を用いて、直径 $1480 \mathrm{~mm}$ 、高さ $1800 \mathrm{~mm}$ の土槽内に 圧力水によるボイリングによって作製した。結果として、相対密度 約 $35 \%\left(\gamma=0.0145 \mathrm{~N} / \mathrm{cm}^{3}\right)$ の地盤となっている。載荷は荷重制 御による 1 サイクル方式で、杭頭沈下量が $40 \mathrm{~mm}$ 以上となるまで 載荷した。なお、実験の詳細については文献 ${ }^{14)}$ を参照されたい。

節部底面支持力 $Q$ について、節数が 3 個の場合の実験值と理論 值との比較図を図 15 に示した。節数が 5 個および 9 個の場合は、 節部底面の支持力が極限値に達する以前に、節の外径に沿う地盤に 円筒状のせん断滑りが起こっていたものと考えられたため除外し た。ここで実験值は、最大荷重時の各節上下の軸方向力差を採用し てある。なお、横軸は地盤の粘着力 $c$ とした。実験地盤については、 三軸圧縮試験によって $\phi=34^{\circ} 、 c=0.5 \mathrm{~N} / \mathrm{cm}^{2}$ を得ているが、 $c$ についてはある程度試験誤差があると考えられたため、理論值は $c$

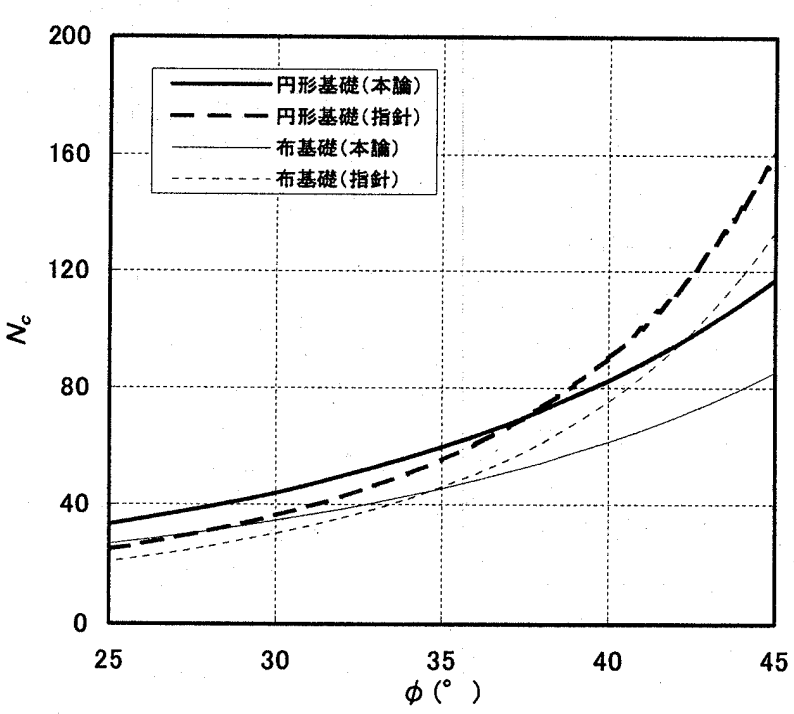

図11 支持力係数 $N_{c}$
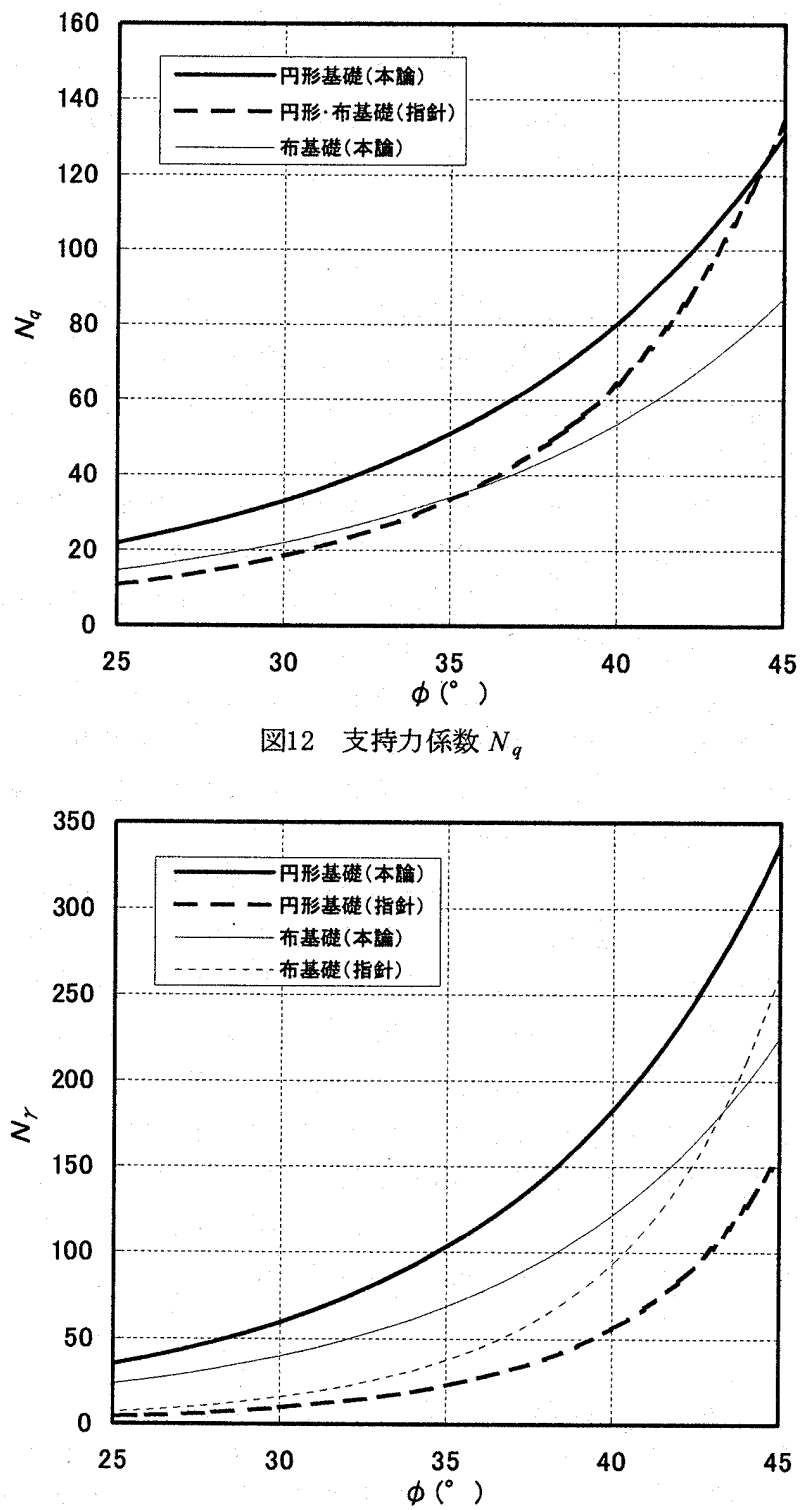

図13 支持力係数 $N_{y}$ 
$=0 \sim 0.5 \mathrm{~N} / \mathrm{cm}^{2}$ の範 囲で算定した。また、2 節でも述べたごとく、 極限時の地盤の破壊領 域、特に地表面付近に おいては、放射状のク ラックなどが生じるこ とを想定して、 $K_{\theta}=0$ としてある。同図にお いて、梁さ $7 \mathrm{~cm}$ (上段 の節部底面）および $31 \mathrm{~cm}$ (中段の節部底 面）の理論值は、 $c=$

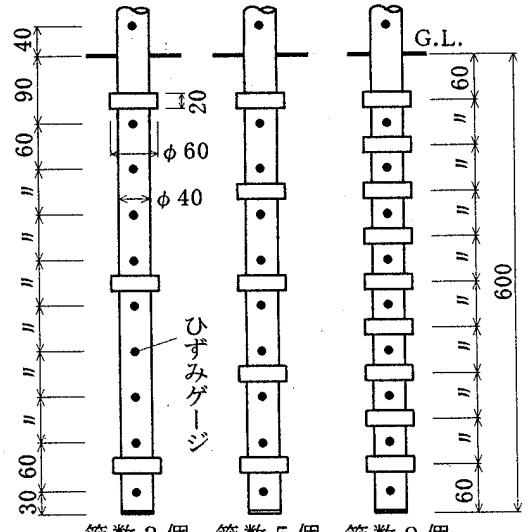

節数 3 個 節数 5 個 節数 9 個

図14 模型杭姿図 (単位: mm)
$0.4 \mathrm{~N} / \mathrm{cm}^{2}$ で実験值と

よい一致を示しているが、深さ $55 \mathrm{~cm}$ （下段の節部底面）について は実験值に他の染さとは傾向の違いがあり、 $K_{\theta}$ が増加する傾向ある Wは $c=0.1 \mathrm{~N} / \mathrm{cm}^{2}$ 付近で理論値が一致していることが分かる。

図 16 に杭先端支持力 $R_{p}$ の理論值と実験值とを比較して示した。 同図では、 $K_{\theta}=0$ および 0.1 の場合の理論值を併記してある。理論 值は $c$ および $K_{\theta}$ にかなり影響されるが、これらの值を適切に評価 できれば、十分に適用できるといえる。

\section{5.まとめ}

以上本論では、節付き場所打ちコンクリート杭を想定して、軸対 称モデルによる節部底面の極限支持力算定式を誘導した。また、模 型実験結果との比較によって、算定式の妥当性を確認した。本算定 式の特徴を挙げると以下のとおりである。

(1)本算定式は、軸対称問題の特徵を有しており、軸部半径に対す


係数 $K_{\theta}$ ) を考慮していることから、従来の平面問題に基づいた支 持力式より適用性が高いものと言える。

(2)本算定式は、 $\omega=0$ の場合は布基礎に、また $\omega=\infty$ 場合は円 形基礎に相当しており、杭先端の極限支持力式としても適用できる。 このことは、従来の円形基礎に対する形状係数による補正を理論的 に解明する系口を与えている。

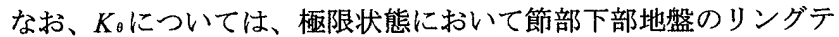
ンションによる緩みなどによって比較的小さい值と考えられるが、 現時点では定量的に評価しがたい。今後、支持力モデルの検討も含 めて、実験やシミュレーション解析などによって明らかにしたい。

本研究は平成 13 年度の中小企業総合事業団が募集した「課題対 応技術革新促進事業（課題対応新技術研究開発事業）」に関して太 洋組株式会社（共同研究体：地建工業株式会社）がプロジェクト名 「リブ付場所打ちコンクリート杭に関する研究開発」について採択 を受け、その一環として実施したものである。

\section{参考文献}

1）薮内貞男：摩擦杭（節付き)，基礎工, Vol.11，No.6, pp.36 44, 1983.6

2) Mohan, D., Murthy, V.N.S. and Jain, G.S. : Design and Construction of Multi-Under-Reamed Piles, Proc. of 7th ICSMFE, Vol.2, pp.183186, 1969

3）山有邦男, 平尾幸太郎, 大杉富美一：節杭の鉛直支持力, 第 17 回土質

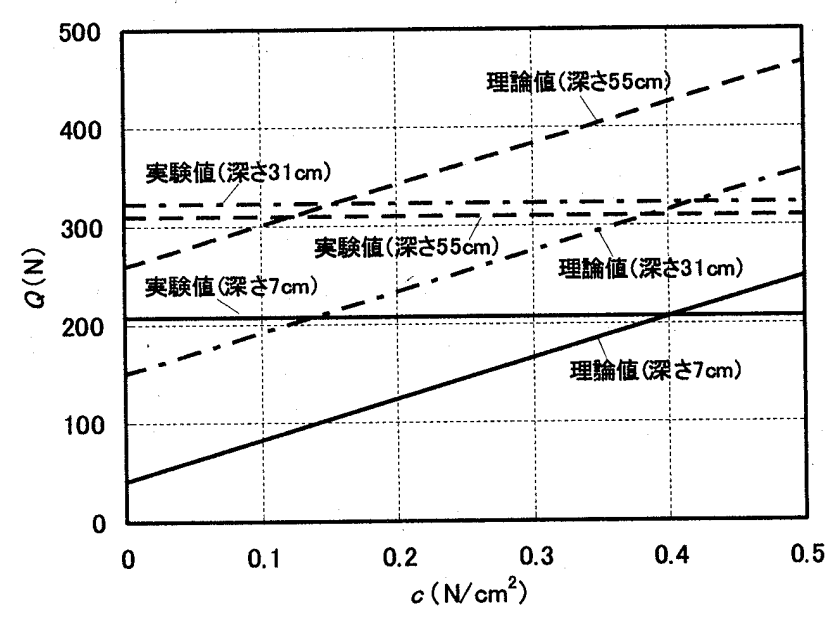

図15 節部底面支持力 $\left(K_{\theta}=0\right)$

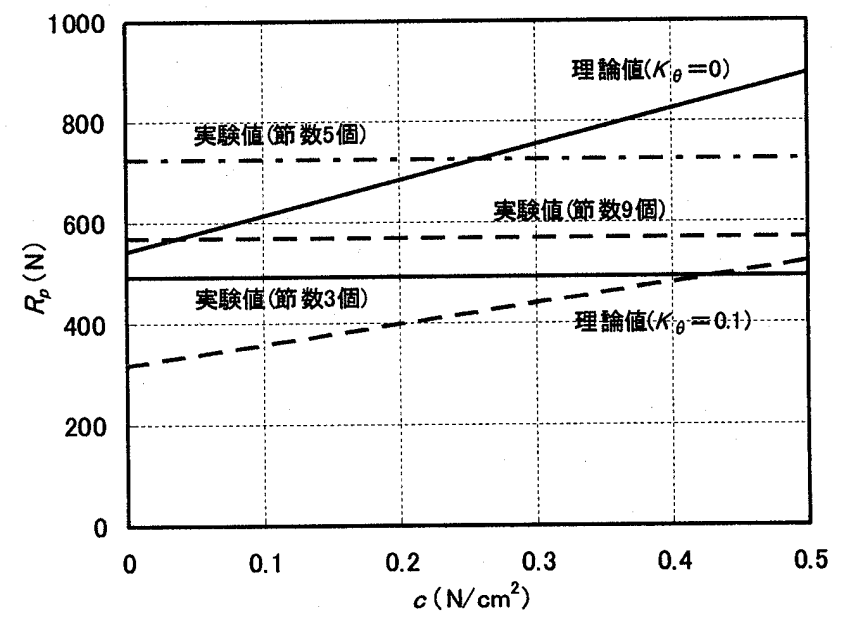

図16 杭先端支持力

工学研究発表会, pp.2101 2104, 1982.5

4）小椋仁志, 山肩邦男, 岸田英明：模型実験による節付き円筒杭の支持力 特性の検討, 日本建筑学会構造系論文報告集, No.374, pp.87 97, 1987.4

5）䜹内貞男, 山下啓明, 上紺屋好行, 平山英喜: 砂中の節杭・コルゲート 杭のモデル実験, 第 26 回土質工学研究発表会, pp.1351 1354, 1991.7

6）石堂稔: 砂地盤における節杭の支持力, 九州産業大学工学部研究報告, 第 6 号, pp. $40 \sim 50,1969.5$

7）石堂稔: 粘性土中の節杭の支持力, 九州産業大学工学部研究報告, 第 8 号, pp.12 23, 1971.6

8）小椋仁志, 山肩邦男：節杭の荷重～沈下量関係の理論解析手法, 日本建 築学会構造系論文報告集, No.393, pp.152 164，1988.11

9）伊藤 仁, 八尾眞太郎, 伊藤淳志, 桝井 健 : 異形場所打ちコンクリ一 卜杭の節部底面支持力算定式について，日本建筑学会大会，B-1, pp.549 $\sim 550,2000.9$

10）伊藤淳志，八尾寅太郎，桝井 健，伊藤 仁：異形場所打ちコンクリー 卜杭の鉛直支持力特性, 第 36 回地盤工学研究発表会, pp.1583 1584, 2001.6

11）土質工学会 : 杭基礎の設計法とその解説，pp. $269 \sim 277,1985.12$

12）日本建築学会：建築基礎構造設計指針, pp105 109, 2001.10

13) Terzaghi, K. : Theoretical Soil Mechanics, pp.118-134, John Wiley \& sons, 1943

14）八尾氲太郎, 伊藤淳志, 伊藤 仁 : 砂地盤における異形杭の鉛直荷重一 沈下性状に関する模型実験、日本建築学会大会, B-1, pp.551 552, 2000.9 